\title{
S. Chaouche, La Mise en scène du répertoire à la Comédie-Française (1680-1815)
}

\section{Monica Pavesio}

\section{Q OpenEdition}

1 Journals

\section{Edizione digitale}

URL: http://journals.openedition.org/studifrancesi/1147

DOI: 10.4000/studifrancesi. 1147

ISSN: 2421-5856

Editore

Rosenberg \& Sellier

\section{Edizione cartacea}

Data di pubblicazione: 1 novembre 2014

Paginazione: 593-594

ISSN: 0039-2944

\section{Notizia bibliografica digitale}

Monica Pavesio, «S. Chaouche, La Mise en scène du répertoire à la Comédie-Française (1680-1815) », Studi Francesi [Online], 174 (LVIII | III) | 2014, online dal 01 novembre 2014, consultato il 18 septembre 2020. URL : http://journals.openedition.org/studifrancesi/1147 ; DOI : https://doi.org/10.4000/

studifrancesi. 1147

Questo documento è stato generato automaticamente il 18 settembre 2020.

\section{(c) 9 (i) $\Theta$}

Studi Francesi è distribuita con Licenza Creative Commons Attribuzione - Non commerciale - Non opere derivate 4.0 Internazionale. 


\title{
S. Chaouche, La Mise en scène du répertoire à la Comédie-Française (1680-1815)
}

\author{
Monica Pavesio
}

\section{NOTIZIA}

S. CHAOUCHE, La Mise en scène du répertoire à la Comédie-Française (1680-1815), Paris,

Champion, 2013, 2 voll. pp. 961.

1 I due volumi di S. Chaouche, studiosa dell'estetica e della pratica teatrale del XVII e XVIII secolo, contengono uno studio globale della messa in scena delle pièces alla ComédieFrançaise dall'anno della sua creazione, il 1680, al 1815, data dell'ultimo inventario prima della riunione definitiva delle due troupes, in cui si era scissa la compagnia principale all'epoca della Rivoluzione. Il periodo di maggiore interesse va dal 1765 al 1793, epoca in cui con solerzia e meticolosità il segretario Delaporte ha lasciato annotazioni chiare e precise del repertorio della compagnia, ma Chaouche ricostruisce, utilizzando documenti inediti, la programmazione precisa, anche degli anni relativi alla fine del XVII secolo. La prima parte del lavoro è dedicata al concetto di "mise en scène" nel XVII e XVII secolo, la seconda parte è consacrata alla scenografia, alla recitazione e alla posizione degli attori sulla scena, ai costumi di scena e a tutti gli elementi che permettono una ricostruzione dell'estetica della messa in scena nei due secoli presi in esame. I volumi sono arricchiti da un apparato iconografico, da numerosi annessi con documenti, schemi, tabelle sulla produzione della Comédie-Française, da un meticoloso glossario, da una bibliografia di più di un centinaio di pagine, da un indice dei nomi. 